\title{
Using Disaggregated Return on Assets to Conduct a Financial Analysis of a Commercial Bank Using an Extension of the DuPont System of Financial Analysis
}

\author{
Jr. Carl B. McGowan (Corresponding author) \\ Norfolk State University \\ 700 Park Avenue, Norfolk, VA 23504
}

Tel: 1-757-275-6876 E-mail: cbmcgown@nsu.com

Andrew R. Stambaugh

Norfolk State University

700 Park Avenue, Norfolk, VA 23504

Tel: 1-757-823-8806 E-mail: a.r.stambaugh@spartans.nsu.edu

Received: March 14, 2012

doi:10.5430/afr.v1n1p152
Accepted: April 11, 2012

Published: May 15, 2012

URL: http://dx.doi.org/10.5430/afr.v1n1p152

\begin{abstract}
In this paper, we use an expanded version of the DuPont system of financial analysis to perform a financial analysis of a bank using disaggregated data to computer return on assets. The DuPont system of financial analysis is based on return on equity which is based on net profit margin, total asset turnover, and the equity multiplier. We further disaggregate net profit margin into three components: return on loans, return on securities, and return on other assets using supplementary data provided in the SEC filings of Monarch Bank. The analysis covers the period from 2003 to 2010. Our analysis demonstrates that return on assets for Monarch Bank derives primarily from return on loans. That is, $86 \%$ of the investment weighted return on assets for Monarch Bank derives from return on loans.
\end{abstract}

Keywords: Bank management, Financial analysis, DuPont system of financial analysis

\section{Introduction}

The goal of corporate managers is to maximize the value of the firm. This goal is true for financial institutions such as banks. The value of the firm is determined by the investment and financing decisions made by the managers of the firm. Investment decisions determine the assets bought by the firm and financing decisions determine the extent to which assets are financed with debt. The investment and financing decisions made by managers determine the expected value of future cash flows of the firm and the riskiness of those expected future cash flows. The probability distribution of expected future cash flows can be used to estimate the value of the firm. The market value is the expected future cash flow divided by the cost of capital for the firm. The analyst or manager can estimate the market value of the bank using the expanded DuPont model of financial analysis.

\section{Monarch Bank}

Monarch bank is the wholly-owned subsidiary of Monarch Financial Holdings, Inc. whose headquarters is located in Chesapeake, Virginia. The bank operates two subsidiaries, Monarch Investment, LLC and Monarch Capital, LLC and participates in other markets through joint ventures and the use of business partners. The bank incorporated in 1998 and opened its doors to business as a chartered member of the Federal Reserve Bank in the spring of 1999. The holding company was created mid-2006 as part of a reorganization plan for the financial institution. Currently, the bank operates nine banking offices, six residential mortgage offices, and a single investment services office in Chesapeake, Norfolk, and Virginia Beach, Virginia. The company's 2010 filings indicate that Monarch Bank employs 527 individuals, 514 of which are full-time. Real estate financing comprises Monarch's core business. The company currently serves the markets of southeastern Virginia and Northeastern North Carolina. As noted in company statements, although the institution has 
quickly expanded over the short period since its founding, the company aims "to do so profitably and without compromising (our) asset quality."

\section{A Financial Analysis Model for Financial Institutions}

As presented in Saunders (2000) and discussed in Collier, McGowan, and Sulong (2005) and Collier, Collier, McGowan, and Muhammad (2009), the DuPont system of financial analysis is one based on return on equity. According to the formula, the three elements of return on equity are net profit margin, total asset turnover, and the equity multiplier. Net profit margin alludes to a company's profitability in regards to their ability to control costs. A more profitable company with more control over costs would exhibit a profit margin higher than competitors. Total Asset Turnover is a measure of a company's efficiency in using assets to generate sales. The higher that this ratio the better. The equity multiplier is a measure of leverage. A higher equity multiplier ratio shows that an institution is relying more heavily on debt financing to obtain funds. As implied, these ratios can be useful tools in comparing a company to its competitors or overall industry. Return on equity, as computed from the other three ratios, is a measure of profitability, suggesting how much profit is being generated with investors' money. Through use of these ratios, we are able to construct pro forma financial statements.

Return on equity can be split into return on assets and the equity multiplier. Return on assets can be further disaggregated into net profit margin and total asset turnover:

$$
\begin{aligned}
& \mathrm{ROE}=(\mathrm{ROA}) *(\mathrm{EM}) \\
& \mathrm{ROA}=(\mathrm{NPM}) *(\mathrm{TAT}) \\
& \mathrm{ROE}=(\mathrm{NPM}) *(\mathrm{TAT}) *(\mathrm{EM}) \\
& \text { Where } \\
& \mathrm{ROE}=\text { Return on Equity } \\
& \mathrm{ROA}=\text { Return on Assets } \\
& \mathrm{EM}=\text { Equity Multiplier } \\
& \mathrm{NPM}=\text { Net Profit Margin } \\
& \text { TAT }=\text { Total Asset Turnover }
\end{aligned}
$$

Net profit margin is calculated as net profit or loss divided by total revenue. Total asset turnover is calculated as total revenue divided by total assets. The equity multiplier is calculated as total assets divided by total stockholders' equity:

$$
\begin{aligned}
& \mathrm{NPM}=(\mathrm{NI}) /(\mathrm{TR}) \\
& \mathrm{TAT}=(\mathrm{TR}) /(\mathrm{TA}) \\
& \mathrm{EM}=(\mathrm{TA}) /(\mathrm{TSE})
\end{aligned}
$$

Where,

$$
\begin{aligned}
& \text { NPM = Net Profit Margin } \\
& \text { NI = Net Income } \\
& \text { TR = Total Revenue } \\
& \text { TAT }=\text { Total Asset Turnover } \\
& \text { TA = Total Assets } \\
& \text { EM = Equity Multiplier } \\
& \text { TSE = Total Stockholders' Equity }
\end{aligned}
$$

\section{Further Disaggregation of DuPont as Applies to Financial Institutions}

Banks differ significantly from other institutions to which the DuPont system of financial analysis is applied. Loans make up the vast majority of a bank's assets, and interest on these holdings comprise a large proportion of total income for the typical bank. Furthermore, owner's equity composes merely ten percent of the institutions liabilities. Consequently, the principal struggle in banking involves balancing the objectives of solvency and liquidity against that of profitability. To efficiently achieve these goals, a substantial amount of complex consideration goes into the management of a bank's portfolio, paying particular interest to risk management in regards to asset selection. 
Monarch Bank's SEC filings are distinguished from some other financial institutions in that the bank explicitly lists the average annual balances of total loans, securities, and other assets, as well as the income derived from these asset categories. From this information, return from each category can be calculated in isolation. Assigning a weight to each category, we can then determine the individual weighted returns from loans, securities, and other assets. By doing so, we have essential demonstrated a model for the disaggregation of return on assets by asset type. The formula is illustrated as follows:

$\mathrm{ROE}=(\mathrm{ROA}) *(\mathrm{EM})$

$\mathrm{ROE}=\left(\mathrm{R}_{\mathrm{L}}\left(\mathrm{W}_{\mathrm{L}}\right)+\mathrm{R}_{\mathrm{S}}\left(\mathrm{W}_{\mathrm{S}}\right)+\mathrm{R}_{\mathrm{O}}\left(\mathrm{W}_{\mathrm{O}}\right)\right)^{*}(\mathrm{EM})$

Where,

$\mathrm{R}_{\mathrm{L}}=$ Return on Loans, calculated as income from loans divided by total loans.

$\mathrm{R}_{\mathrm{S}}=$ Return on Securities, calculated as income from securities divided by total securities

$\mathrm{R}_{\mathrm{O}}=$ Return on Other Assets, calculated as income from other assets divided by total other assets

$\mathrm{W}_{\mathrm{L}}=$ Weight of Loans, calculated as total loans divided by total assets

$\mathrm{W}_{\mathrm{S}}=$ Weight of Securities, calculated as total securities divided by total assets

$\mathrm{W}_{\mathrm{O}}=$ Weight of Other Assets, calculated as total other assets divided by total assets

\section{Financial Analysis of Monarch Bank - Balance Sheet Items}

The financial statements are summarized in Table 1. Monarch has four major asset categories: cash and cash equivalents, investment securities, loans, and other assets. Cash and cash equivalents consist of federal funds sold, vault cash, and interest-bearing balances. Investment securities include both those securities held-to-maturity at cost and those securities available-for-sale at fair value. The loan account consist of an allowance of loans available for sale and loans issued, net of unearned income, net ofan allowance for loan losses. Other assets include property and equipment net of depreciation, restricted equity securities, and other assets not explicitly described. As stated in company filings, restricted equity securities are securities that do not have a readily determinable fair value and lack a market.Cash and cash equivalents have experienced considerable volatility over the period, increasing by nearly three-hundred percent between 2004 and 2005 from a low of \$5.2 million. Cash and cash equivalents would fall the years following 2006 until again experiencing rapid growth reaching an all time high of $\$ 34.4$ million in 2009. The average figure for the period in study is $\$ 15.7$ million. Over the period, investment securities have declined by an astounding amount. Valued at as much as $\$ 50$ million in 2006, securities holdings dropped as low as $\$ 6.3$ million in 2008 and have since rebounded to $\$ 17.6$ million. The average balance during the period is $\$ 27.4$ million. Loans have remained the most substantial asset category on the balance sheet and have increased every year during the seven year period with an average annual growth rate of roughly $28 \%$. Lowest in 2003 at $\$ 134.2$ million, the value of loans has grown to approximately $\$ 725.2$ million in 2010 . The average value of loans for the period is $\$ 402.0$ million. Other assets have also steadily grown in value during the period. The average annual growth rate exhibited in this category is approximately $40 \%$. The average value of other assets during the period is $\$ 25.4$ million with a high of $\$ 55.3$ million in 2010 and a low of $\$ 5.7$ million in 2003.

The bank has three major liability accounts: customer deposits, borrowings, and other liabilities. Deposits include both interest-bearing and noninterest-bearing accounts. Borrowings include federal funds purchased, securities sold on repurchase agreements, federal home loan bank advances, and other short-term borrowings. Other liabilities are not explicitly described. Deposits have grown steadily throughout the period with an average annual growth rate of $26 \%$. The average value of deposits is $\$ 379.1$ million with a low of $\$ 143.1$ million in 2003 and a high of $\$ 705.6$ million in 2010. Borrowings have exhibited volatility peaking first in 2007 and again in 2009, reaching a high of $\$ 76.1$ million in 2009 and being at the lowest value of $\$ 20.6$ million in 2003. Borrowings has since dropped from the seven year high to $\$ 40.3$ million in 2010. The average figure during the period is $\$ 45.9$ million. With the exception of the period from 2007 to 2008 , other liabilities have also grown steadily during the 7 year period, sometimes doubling in one year. The average annual growth rate is $58 \%$. Other liabilities were lowest in value in 2003 at $\$ 552$ thousand and highest in value at $\$ 7.9$ million in 2010. The average amount of other liabilities is $\$ 2.9$ million.

\section{Financial Analysis of Monarch Bank - Income Statement Items}

Monarch Bank receives income from two major channels: interest income and non-interest income. Interest income consists of interest on fees and loans, interest on investment securities, interest on federal funds sold, dividends on equity securities, and other interest income. Non-interest income includes income from mortgage banking, service charges and fees, gains or losses on the sale of investment securities, and other noninterest income. 
The primary expense categories are interest and noninterest expenses. Interest expenses include interest on deposits and interest on borrowings. Noninterest expenses include salaries and employee benefits, occupancy expense, furniture and equipment expense, data processing service charges, loan origination expenses, Virginia Franchise Tax, advertising and marketing expenses, and other noninterest expenses. Net income from minority interests is added and income taxes and a provision for loan losses are then expensed to arrive at net income.

\section{Discussion of Financial Ratios}

Financial ratios are in Table 2 and Graphs of the financial ratios are in Figures1-5. As a percent of total assets, cash and cash equivalents have fluctuated around an average of 3.3\%, with a low of $1.4 \%$ in 2008 and a high of $5.0 \%$ in 2009 . Investment securities exhibit a substantial decline with a high of $20.6 \%$ in 2003 and a low of $1.0 \%$ in 2009 . Securities average $8.6 \%$ for the period in study. Loans fluctuate from a low of $73.0 \%$ in 2003 to a high of $92.3 \%$ in 2008 , averaging $83.2 \%$ of total assets. Other assets average $4.9 \%$, increasing over the period from a low of $3.1 \%$ in 2003 to a high of $6.7 \%$ in 2010 .

As a percentage of total liabilities, deposits averaged $79.6 \%$, borrowings averaged $10.7 \%$, and other liabilities averaged .5\%. Customer deposits were at their highest percentage in 2010 at $85.5 \%$ and lowest percentage in 2004 at $75.5 \%$. Borrowings were at their highest percentage in 2007 at $14.6 \%$ and lowest percentage in 2010 at $4.9 \%$. Other liabilities were at their highest percentage in 2010 at $1.0 \%$ and lowest percentage in 2003 at $0.1 \%$.

As a percentage of total revenue, interest expense was at its highest in 2006 at $37.8 \%$ and lowest in 2010 at $9.5 \%$ with an average of $27.2 \%$ during the period. Noninterest expense was at its highest in 2010 at $70.7 \%$ and lowest in 2006 at $41.4 \%$ with an average of $56.3 \%$. Provisions for loan losses were at their highest percentage of total revenue in 2008 at $9.9 \%$ and lowest in 2006 at 1.9\%, averaging5.1\%. Income tax expense was at its highest in 2006 at $6.2 \%$ and lowest in 2008 at $1.0 \%$ with an average of $3.7 \%$.

\section{DuPont Analysis of Monarch Bank}

The DuPont Analysis is in Table 2. Based on the computations derived from the use of the consolidated statements, return on equity for Monarch Bank exhibits an average of 6.24\%, but ranges from a high of $10.65 \%$ in 2006 to a low of $1.89 \%$ in 2008 . Net profit margin averages $7.54 \%$ with a range from a high of $12.64 \%$ in 2006 to a low of $2.24 \%$ in 2008 . Total asset turnover averages 0.075 times with a range from 0.048 times in 2003 to 0.112 times in 2010 . The equity multiplier averages 11.04 with a range from 9.14 times in 2003 to 13.75 times in 2007.

Return on equity volatility stems from significant variability in component parts: net profit margin, total asset turnover, and the equity multiplier. Institutions in the financial industry tend to exercise a higher level of financial leverage and, consequently, exhibit high equity multipliers. Considering, by removing the equity multiplier we are able to determine exactly how much of the return on equity was derived from profit margin and revenue.In 2003, $0.29 \%$ of return on equity was derived from sales and profit margin where the bank's financial leverage contributed 2.39\%. In 2004, $0.33 \%$ of the return on equity was derived from sales and profit margin and financial leverage contributed 3.25\%. In 2005, $0.63 \%$ of the return on equity was derived from sales and profit margin andfinancial leverage contributed $6.42 \%$. In $2006,0.89 \%$ of the return on equity was derived from sales and profit margin andfinancial leverage contributed $9.77 \%$. In $2007,0.633 \%$ ofthe return on equity was derived from sales and profit margin and financial leverage contributed $8.00 \%$.In $2008,0.19 \%$ of the return on equity was derived from sales and profit margin and financial leverage contributed $1.70 \%$. In $2009,0.70 \%$ of the return on equity was derived from sales and profit margin and financial leverage contributed $6.43 \%$. In $2010,0.72 \%$ of the return on equity was derived from sales and profit margin andfinancial leverage contributed $7.57 \%$.

\section{Discussion of Return on Assets Disaggregation}

The Interest Income Analysis is in Table 3. Based on calculations derived from the use of supplementary data found in the bank's SEC filings entitled Interest Income Analysis, return on assets in 2003 was 4.86\%. Weighted return on loans comprised $4.31 \%$ of this return while securities and other assets contributed $0.51 \%$ and $0.04 \%$, respectively. Return on assets in 2004 was $4.88 \%$. Return on loans comprised $4.48 \%$ of this return while securities and other assets contributed $0.34 \%$ and $0.06 \%$, respectively. In 2005 , Return on assets was $6.07 \%$. Loans made up $5.71 \%$ of this return while securities and other assets contributed $0.24 \%$ and $0.12 \%$, respectively. In 2006 , return on assets was $7.39 \%$. Weighted return on loans comprised $6.86 \%$ of this return while securities and other assets contributed $0.23 \%$ and $0.30 \%$, respectively. Total asset yield for 2007 was 7.56\%. Weighted return on loans comprised 7.25\% of this return while securities and other assets contributed $0.14 \%$ and $0.17 \%$, respectively. In 2008 , asset yield was $5.64 \%$. Weighted return on loans comprised $5.43 \%$ of this return while securities and other assets contributed $0.09 \%$ and $0.12 \%$, respectively. Return on assets in 2009 was $5.07 \%$. Weighted return on loans comprised $4.95 \%$ of this return while securities and other 
assets contributed $0.04 \%$ and $0.08 \%$, respectively. Finally, return on assets for 2010 was $5.10 \%$. Weighted return on loans comprised $5.00 \%$ of this return while securities and other assets contributed $0.02 \%$ and $0.08 \%$, respectively.Over the eight year period, average return on loans is $6.41 \%$ and comprises $86 \%$ of return, average return on securities is $3.47 \%$ and comprises $6 \%$ of return, and return on other assets is $1.4 \%$ and comprises $8 \%$ of return. Return is primarily driven by loans followed by other assets and then securities. Monarch Bank reduced investment in securities by $76 \%$.

\section{Summary and Conclusions}

This paper applies a model for the financial analysis of a bank using the DuPont system of financial analysisas presented in Saunders (2000) and applied in Collier, McGowan, and Sulong (2005) and Collier, McGowan, and Muhammad (2009). Return on equity of the bank is disaggregated into three parts: net profit margin, total asset turnover, and the equity multiplier due to leverage. The DuPont system of financial analysis tracks the performance of Monarch Bank.From analysis of the ratios derived from consolidated statements, Monarch Bankuses deposits and debt tofinance the Bank. Monarch Bank derives most of its return from the loan portfolio followed by other assets and the securities portfolio. In reference to the disaggregation of return on assets, note that return on assets as calculated using the supplementary data listed under Interest Income Analysis differs from return on assets that as calculated using consolidated financial statements. This is attributed to disparity in net income and differences in the presentation of total assets. Nevertheless, the supplementary data serves well to demonstrate the application of the disaggregation of return on assets. Given our limited familiarity with the methods used to produce the supplementary data, the return on assets figures calculated using the consolidated statements are assumed to be correct. In reference to the banks portfolio composition, it appears that Monarch has reduced its holdings in marketable securities. Perhaps management has adopted this conservative approach because of the uncertainty created by the conditions exhibited in the financial and real estate markets during prior years. Yet, it does not appear that this has negatively affected management's ability to act on behalf of shareholders as measured by return on equity.

\section{References}

Collier, H., McGowan, C. and Muhammad, J. (2009). "Financial Analysis of AFFIN Bank Berhad: The Evolution of a Financial Institution," Southwest Review of International Business Research, Volume 20, Number 1, 219-227.

Collier, H, McGowan, C., and Sulong, Z. (2005). Financial Institution Analysis in an Evolving Environment: The Case of the Hong Leong Bank BHD, Proceedings of the 2005 Applied Business Research Conference, Orlando, Florida, paper $189 \mathrm{~b}$.

Monarch Bank SEC Filings, 2004-2010.

Saunders, A. (2000). Management of Financial Institutions, Third Edition, McGraw Hill. 
Table 1. Monarch Bank Financial Statements

\begin{tabular}{|c|c|c|c|c|c|c|c|c|c|}
\hline \multicolumn{10}{|c|}{ (Figures in U.S. Dollars) } \\
\hline $\begin{array}{l}\text { Income Statement } \\
\text { - Income }\end{array}$ & 2003 & 2004 & 2005 & 2006 & 2007 & 2008 & 2009 & 2010 & Average \\
\hline $\begin{array}{l}\text { Interest Bearing } \\
\text { Income }\end{array}$ & 7575619 & 9392139 & 15527006 & 25110447 & 30939106 & 30867332 & 32517659 & 39272833 & 23900268 \\
\hline $\begin{array}{l}\text { Non-Interest } \\
\text { Bearing Income }\end{array}$ & 1175887 & 2396140 & 3149902 & 3585758 & 8192467 & 19804185 & 35634257 & 53503388 & 15930248 \\
\hline Total Revenue & 8751506 & 11788279 & 18676908 & 28696205 & 39131573 & 50671517 & 68151916 & 92776221 & 39830516 \\
\hline $\begin{array}{l}\text { Income Statement } \\
\text { - Expenses }\end{array}$ & 2003 & 2004 & 2005 & 2006 & 2007 & 2008 & 2009 & 2010 & Average \\
\hline Interest Expense & 2787794 & 3232142 & 5507068 & 10860686 & 14486625 & 14715983 & 10421158 & 797554 & 8851126 \\
\hline $\begin{array}{l}\text { Noninterest } \\
\text { Expense }\end{array}$ & 49951 & 7112903 & 9087911 & 11869592 & 18812405 & 29022845 & 45034344 & 65582856 & 23946601 \\
\hline $\begin{array}{l}\text { Provision for Loan } \\
\text { Losses }\end{array}$ & 205000 & 305042 & 915014 & 559344 & 976478 & 5014076 & 5183747 & 8639292 & 2724749 \\
\hline $\begin{array}{l}\text { Income Tax } \\
\text { Expense }\end{array}$ & 158834 & 373685 & 1065084 & 1785706 & 1533309 & 504500 & 2452970 & 3544532 & 1427328 \\
\hline Total Expenses & 8201579 & 11023772 & 16575077 & 25075328 & 35808817 & 49257404 & 63092219 & 86564234 & 36949804 \\
\hline $\begin{array}{l}\text { Minority Interests } \\
\text { in Subsidiary's Net } \\
\text { Income }\end{array}$ & 9165 & 7453 & 0 & -5581 & 164582 & 281230 & 204025 & 262596 & 115434 \\
\hline Net Loss/Income & 540762 & 57054 & 2101831 & 3626458 & 3158174 & 1132883 & 4855672 & 5949391 & 2765278 \\
\hline $\begin{array}{l}\text { Balance Sheet - } \\
\text { Assets }\end{array}$ & 2003 & 2004 & 2005 & 2006 & 2007 & 2008 & 2009 & 2010 & rage \\
\hline $\begin{array}{l}\text { Cash and Cash } \\
\text { Equivalents }\end{array}$ & 13441 & 28798 & 75674 & 18966342 & 9464550 & 8596342 & 51240 & 75747 & 1517 \\
\hline $\begin{array}{l}\text { Investment } \\
\text { Securities }\end{array}$ & 906274 & 041028 & 36398822 & 50028667 & 30958299 & 6346917 & 7189930 & 17601718 & 3957 \\
\hline Loans & 34269863 & 181298417 & 264834962 & 318634426 & 433969851 & 551035298 & 607397888 & 725218783 & 402082436 \\
\hline Other $A$ & 5746190 & 7289259 & 14664587 & 20090140 & 28771071 & 31219845 & 40629985 & 55386497 & 25474697 \\
\hline Total Assets & 184035768 & 226857502 & 331174045 & 407719575 & 503163771 & 597198402 & 689569043 & 825582745 & 470662606 \\
\hline $\begin{array}{l}\text { Balance Sheet - } \\
\text { Liabilities }\end{array}$ & 2003 & 2004 & 2005 & 2006 & 2007 & 2008 & 2009 & 2010 & rage \\
\hline r Deposits & 3103966 & 171376197 & 273073104 & 314113475 & 389704279 & 496085795 & 540038888 & 705661577 & 379144660 \\
\hline Borrowings & 20615660 & 33812000 & 26976025 & 58075117 & 73531200 & 38060272 & 76158774 & 40282201 & 45938906 \\
\hline Other Liabilities & 173869 & 552967 & 1323165 & 1494853 & 3322094 & 3163645 & 5356227 & 7905470 & 2911536 \\
\hline Total Liabilities & 163893495 & 205741164 & 301372294 & 373683445 & 466557573 & 537309712 & 621553889 & 753849248 & 427995103 \\
\hline $\begin{array}{l}\text { Minority Interest in } \\
\text { Subsidiary }\end{array}$ & 30716 & 0 & 0 & 27619 & 57702 & 111274 & 106857 & 165092 & 62408 \\
\hline $\begin{array}{l}\text { Monarch Financial } \\
\text { Holdings, Inc. } \\
\text { Stockholder's } \\
\text { Equity }\end{array}$ & 557 & 338 & 751 & 8511 & 6548496 & 59777416 & 8297 & 68405 & 42605096 \\
\hline Total Equity & 0142273 & 6338 & 01751 & 34036130 & 36606198 & 59888690 & 68015154 & 71733497 & 42667504 \\
\hline $\begin{array}{l}\text { Total Liabilities } \\
\text { and Shareholders' } \\
\text { Equity }\end{array}$ & 184035768 & 226857502 & 331174045 & 407719575 & 503163771 & 597198402 & 689569043 & 825582745 & 470662606 \\
\hline
\end{tabular}


Table 2. Monarch Bank Ratio Computations

\begin{tabular}{|c|c|c|c|c|c|c|c|c|c|}
\hline Income Statement - Income & 2003 & 2004 & 2005 & 2006 & 2007 & 2008 & 2009 & 2010 & Average \\
\hline Interest Bearing Income & $86.6 \%$ & $79.7 \%$ & $83.1 \%$ & $87.5 \%$ & $79.1 \%$ & $60.9 \%$ & $47.7 \%$ & $42.3 \%$ & $70.9 \%$ \\
\hline Non-Interest Bearing Income & $13.4 \%$ & $20.3 \%$ & $16.9 \%$ & $12.5 \%$ & $20.9 \%$ & $39.1 \%$ & $52.3 \%$ & $57.7 \%$ & $29.1 \%$ \\
\hline Total Revenue & $100 \%$ & $100 \%$ & $100 \%$ & $100 \%$ & $100 \%$ & $100 \%$ & $100 \%$ & $100 \%$ & $100 \%$ \\
\hline Income Statement - Expenses & 2003 & 2004 & 2005 & 2006 & 2007 & 2008 & 2009 & 2010 & Average \\
\hline Interest Expense & $31.9 \%$ & $27.4 \%$ & $29.5 \%$ & $37.8 \%$ & $37.0 \%$ & $29.0 \%$ & $15.3 \%$ & $9.5 \%$ & $27.2 \%$ \\
\hline Non-interest Expense & $57.7 \%$ & $60.3 \%$ & $48.7 \%$ & $41.4 \%$ & $48.1 \%$ & $57.3 \%$ & $66.1 \%$ & $70.7 \%$ & $56.3 \%$ \\
\hline Provision for Loan Losses & $2.3 \%$ & $2.6 \%$ & $4.9 \%$ & $1.9 \%$ & $2.5 \%$ & $9.9 \%$ & $7.6 \%$ & $9.3 \%$ & $5.1 \%$ \\
\hline Income Tax Expense & $1.8 \%$ & $3.2 \%$ & $5.7 \%$ & $6.2 \%$ & $3.9 \%$ & $1.0 \%$ & $3.6 \%$ & $3.8 \%$ & $3.7 \%$ \\
\hline Profit Margin & $6.2 \%$ & $6.4 \%$ & $11.3 \%$ & $12.6 \%$ & $8.1 \%$ & $2.2 \%$ & $7.1 \%$ & $6.4 \%$ & $7.5 \%$ \\
\hline Total Revenue & $100 \%$ & $100 \%$ & $100 \%$ & $100 \%$ & $100 \%$ & $100 \%$ & $100 \%$ & $100 \%$ & $100 \%$ \\
\hline Balance Sheet - Assets & 2003 & 2004 & 2005 & 2006 & 2007 & 2008 & 2009 & 2010 & \begin{tabular}{|l} 
Average \\
\end{tabular} \\
\hline Cash and Cash Equivalents & $3.3 \%$ & $2.3 \%$ & $4.6 \%$ & $4.7 \%$ & $1.9 \%$ & $1.4 \%$ & $5.0 \%$ & $3.3 \%$ & $3.3 \%$ \\
\hline Investment Securities & $20.6 \%$ & $14.6 \%$ & $11.0 \%$ & $12.3 \%$ & $6.2 \%$ & $1.1 \%$ & $1.0 \%$ & $2.1 \%$ & $8.6 \%$ \\
\hline Loans & $73.0 \%$ & $79.9 \%$ & $80.0 \%$ & $78.2 \%$ & $86.2 \%$ & $92.3 \%$ & $88.1 \%$ & $87.8 \%$ & $83.2 \%$ \\
\hline Other Assets & $3.1 \%$ & $3.2 \%$ & $4.4 \%$ & $4.9 \%$ & $5.7 \%$ & $5.2 \%$ & $5.9 \%$ & $6.7 \%$ & $4.9 \%$ \\
\hline Total Assets & $100 \%$ & $100 \%$ & $100 \%$ & $100 \%$ & $100 \%$ & $100 \%$ & $100 \%$ & $100 \%$ & $100 \%$ \\
\hline Balance Sheet - Liabilities & 2003 & 2004 & 2005 & 2006 & 2007 & 2008 & 2009 & 2010 & Average \\
\hline Customer Deposits & $77.8 \%$ & $75.5 \%$ & $82.5 \%$ & $77.0 \%$ & $77.5 \%$ & $83.1 \%$ & $78.3 \%$ & $85.5 \%$ & $79.6 \%$ \\
\hline Borrowings & $11.2 \%$ & $14.9 \%$ & $8.1 \%$ & $14.2 \%$ & $14.6 \%$ & $6.4 \%$ & $11.0 \%$ & $4.9 \%$ & $10.7 \%$ \\
\hline Other Liabilities & $0.1 \%$ & $0.2 \%$ & $0.4 \%$ & $0.4 \%$ & $0.7 \%$ & $0.5 \%$ & $0.8 \%$ & $1.0 \%$ & $0.5 \%$ \\
\hline Total Equity & $10.9 \%$ & $9.3 \%$ & $9.0 \%$ & $8.3 \%$ & $7.3 \%$ & $10.0 \%$ & $9.9 \%$ & $8.7 \%$ & $9.2 \%$ \\
\hline $\begin{array}{l}\text { Total Liabilities and } \\
\text { Shareholders' Equity }\end{array}$ & $100 \%$ & $100 \%$ & $100 \%$ & $100 \%$ & $100 \%$ & $100 \%$ & $100 \%$ & $100 \%$ & $100 \%$ \\
\hline Dupont Ratios & 2003 & 2004 & 2005 & 2006 & 2007 & 2008 & 2009 & 2010 & \begin{tabular}{|l} 
Average \\
\end{tabular} \\
\hline Profit Margin (PM) & $6.18 \%$ & $6.42 \%$ & $11.25 \%$ & $12.64 \%$ & $8.07 \%$ & $2.24 \%$ & $7.12 \%$ & $6.41 \%$ & $7.54 \%$ \\
\hline Asset Utilization (TAT) & 0.0476 & 0.0520 & 0.0564 & 0.0704 & 0.0778 & 0.0848 & 0.0988 & 0.1124 & 0.0750 \\
\hline Equity Multiplier (EM) & 9.1368 & 10.7432 & 11.1126 & 11.9790 & 13.7453 & 9.9718 & 10.1385 & 11.5090 & 11.0420 \\
\hline Return on Equity $=\mathrm{NI} / \mathrm{OE}$ & $2.68 \%$ & $3.59 \%$ & $7.05 \%$ & $10.65 \%$ & $8.63 \%$ & $1.89 \%$ & $7.14 \%$ & $8.29 \%$ & $6.24 \%$ \\
\hline Return on Assets (ROA) & $0.29 \%$ & $0.33 \%$ & $0.63 \%$ & $0.89 \%$ & $0.63 \%$ & $0.19 \%$ & $0.70 \%$ & $0.72 \%$ & $0.55 \%$ \\
\hline $\mathrm{ROE}=\mathrm{PM}^{*} \mathrm{TAT} * \mathrm{EM}$ & $2.68 \%$ & $3.59 \%$ & $7.05 \%$ & $10.65 \%$ & $8.63 \%$ & $1.89 \%$ & $7.14 \%$ & $8.29 \%$ & $6.24 \%$ \\
\hline ROE from $E M=$ ROE-ROA & $2.39 \%$ & $3.25 \%$ & $6.42 \%$ & $9.77 \%$ & $8.00 \%$ & $1.70 \%$ & $6.43 \%$ & $7.57 \%$ & $5.69 \%$ \\
\hline
\end{tabular}


Table 3. Monarch Bank Interest Income Analysis

(Average Balances as measured in thousands of U.S. Dollars)

\begin{tabular}{|c|c|c|c|c|c|c|c|c|c|}
\hline & 2003 & 2004 & 2005 & 2006 & 2007 & 2008 & 2009 & 2010 & Average \\
\hline Total Loans & 119056 & 157126 & 218687 & 291669 & 368368 & 496822 & 588430 & 692744 & 366613 \\
\hline Loan Income/Expense & 6760 & 8638 & 14685 & 23651 & 30057 & 30104 & 32161 & 38935 & 23124 \\
\hline Loan Yield & $5.68 \%$ & $5.50 \%$ & $6.72 \%$ & $8.11 \%$ & $8.16 \%$ & $6.06 \%$ & $5.47 \%$ & $5.62 \%$ & $6.41 \%$ \\
\hline Weight of Loans & $75.96 \%$ & $81.52 \%$ & $85.07 \%$ & $84.59 \%$ & $88.90 \%$ & $89.67 \%$ & $90.62 \%$ & $88.96 \%$ & $85.66 \%$ \\
\hline $\begin{array}{l}\text { Weighted Return on } \\
\text { Loans }\end{array}$ & $4.31 \%$ & $4.48 \%$ & $5.71 \%$ & $6.86 \%$ & $7.25 \%$ & $5.43 \%$ & $4.95 \%$ & $5.00 \%$ & $5.50 \%$ \\
\hline Total Securities & 26301 & 21479 & 17750 & 18772 & 13514 & 12578 & 6363 & 8111 & 15609 \\
\hline $\begin{array}{l}\text { Securities } \\
\text { Income/Expense }\end{array}$ & 792 & 655 & 624 & 778 & 571 & 484 & 235 & 186 & 541 \\
\hline Securities Yield & $3.01 \%$ & $3.05 \%$ & $3.52 \%$ & $4.14 \%$ & $4.23 \%$ & $3.85 \%$ & $3.69 \%$ & $2.29 \%$ & $3.47 \%$ \\
\hline Weight of Securities & $16.78 \%$ & $11.14 \%$ & $6.91 \%$ & $5.44 \%$ & $3.26 \%$ & $2.27 \%$ & $0.98 \%$ & $1.04 \%$ & $5.98 \%$ \\
\hline $\begin{array}{l}\text { Weighted Return on } \\
\text { Securities }\end{array}$ & $0.51 \%$ & $0.34 \%$ & $0.24 \%$ & $0.23 \%$ & $0.14 \%$ & $0.09 \%$ & $0.04 \%$ & $0.02 \%$ & $0.20 \%$ \\
\hline Other Assets & 11369 & 14148 & 20622 & 34366 & 32498 & 44672 & 54563 & 77823 & 36258 \\
\hline $\begin{array}{l}\text { Income/Expense on } \\
\text { Other Assets }\end{array}$ & 66 & 112 & 303 & 1046 & 684 & 649 & 518 & 585 & 495 \\
\hline Other Yield & $0.58 \%$ & $0.79 \%$ & $1.47 \%$ & $3.04 \%$ & $2.10 \%$ & $1.45 \%$ & $0.95 \%$ & $0.75 \%$ & $1.39 \%$ \\
\hline $\begin{array}{l}\text { Weight of Other } \\
\text { Assets }\end{array}$ & $7.25 \%$ & $7.34 \%$ & $8.02 \%$ & $9.97 \%$ & $7.84 \%$ & $8.06 \%$ & $8.40 \%$ & $9.99 \%$ & $8.36 \%$ \\
\hline $\begin{array}{l}\text { Weighted Return on } \\
\text { Other Assets }\end{array}$ & $0.04 \%$ & $0.06 \%$ & $0.12 \%$ & $0.30 \%$ & $0.17 \%$ & $0.12 \%$ & $0.08 \%$ & $0.08 \%$ & $0.12 \%$ \\
\hline Total Assets & 156726 & 192753 & 257059 & 344807 & 414380 & 554072 & 649356 & 778678 & 418479 \\
\hline Net Income & 7618 & 9405 & 15612 & 25475 & 31312 & 31237 & 32914 & 39706 & 24160 \\
\hline Owner's Equity & 16258 & 20571 & 25910 & 31872 & 35641 & 42612 & 63678 & 69246 & 38224 \\
\hline $\begin{array}{l}\text { Total Weighted Return } \\
\text { on Assets: RL(WL) + } \\
\text { RS(WS) + RO(WO) }\end{array}$ & $4.86 \%$ & $4.88 \%$ & $6.07 \%$ & $7.39 \%$ & $7.56 \%$ & $5.64 \%$ & $5.07 \%$ & $5.10 \%$ & $5.82 \%$ \\
\hline $\begin{array}{l}\text { Return on Assets } \\
(\text { ROA): NI/TA }\end{array}$ & $4.86 \%$ & $4.88 \%$ & $6.07 \%$ & $7.39 \%$ & $7.56 \%$ & $5.64 \%$ & $5.07 \%$ & $5.10 \%$ & $5.82 \%$ \\
\hline
\end{tabular}




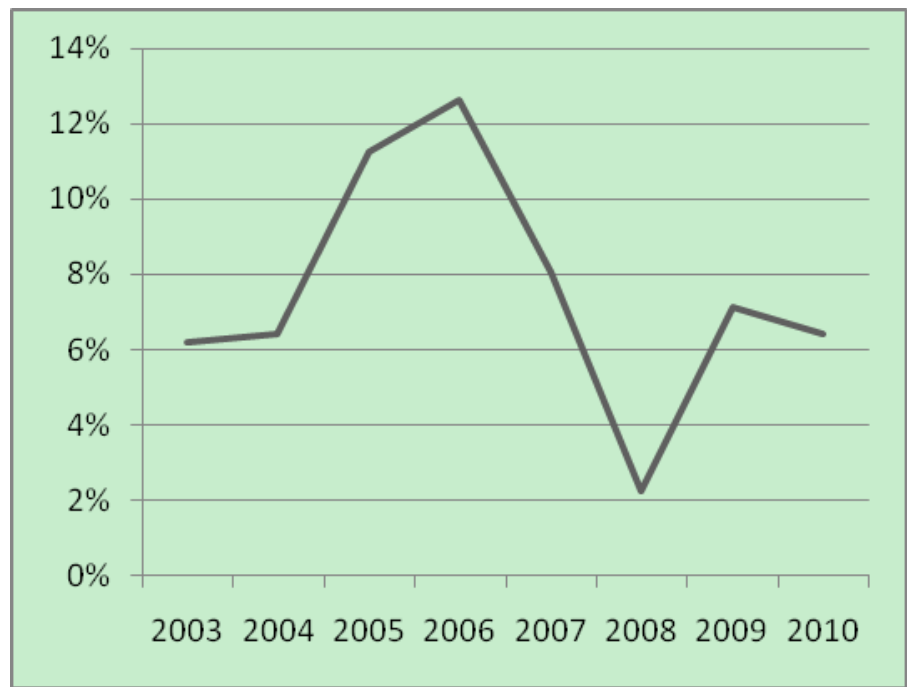

Figure 1. Monarch Bank Profit Margin

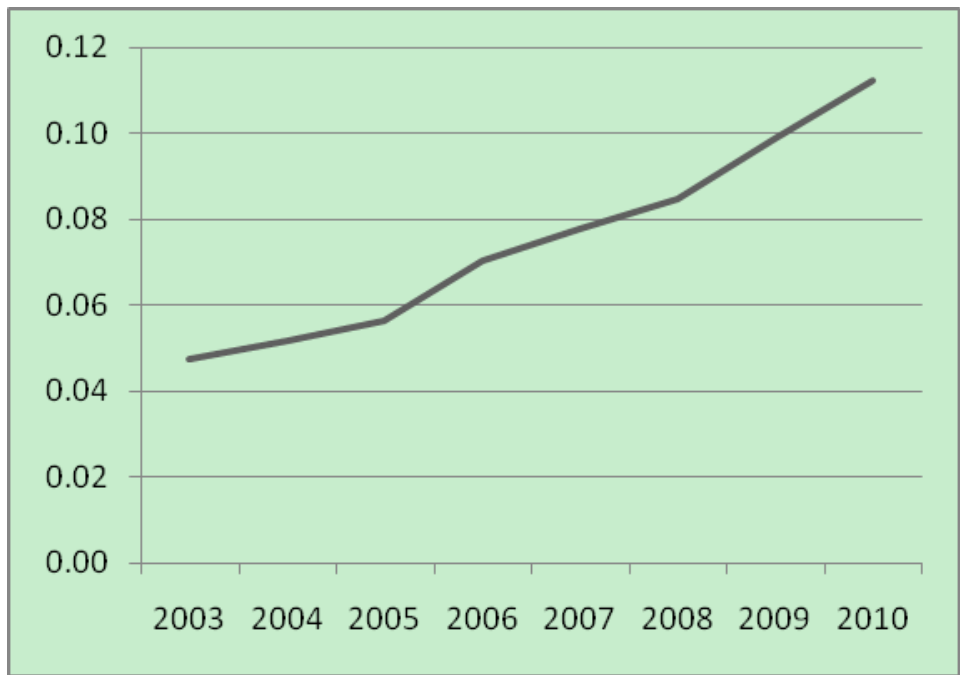

Figure 2. Monarch Bank Total Asset Turnover

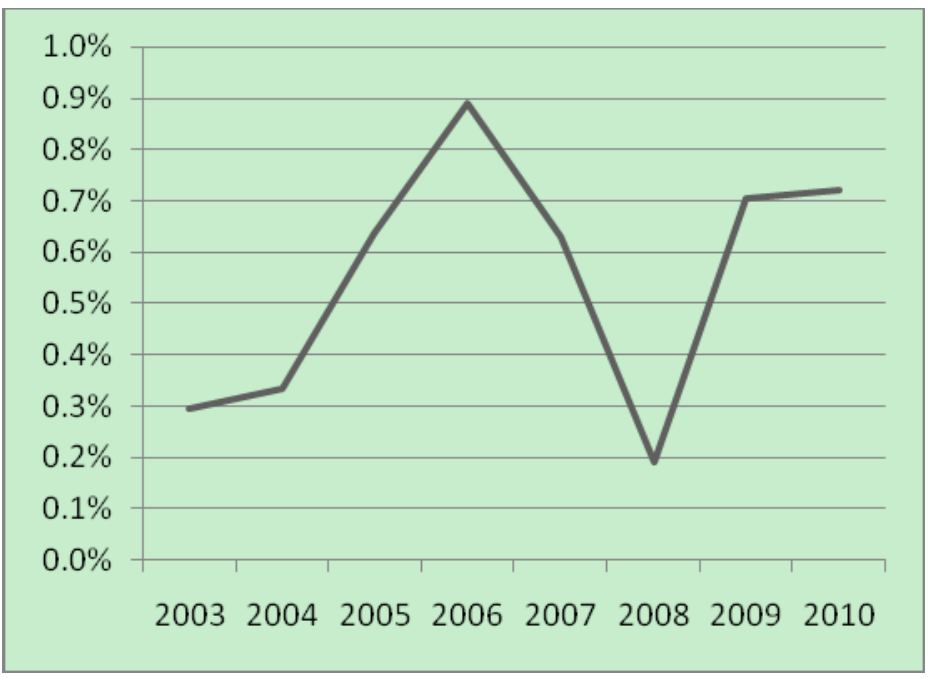

Figure 3. Monarch Bank Return on Assets 


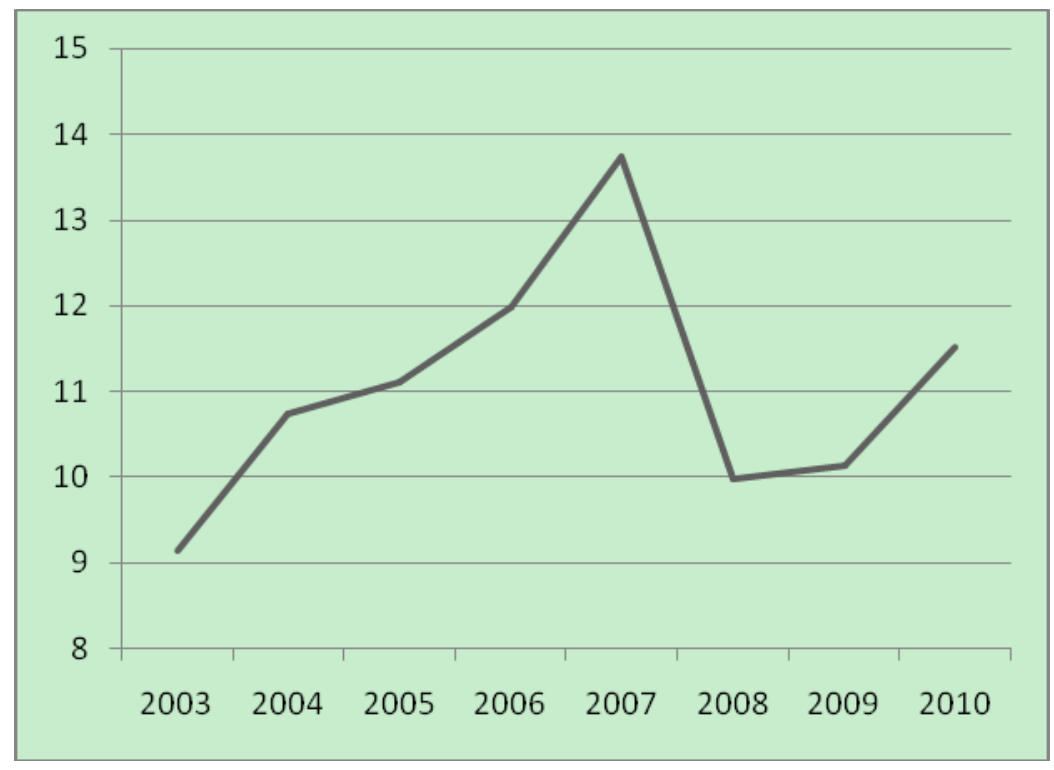

Figure 4. Monarch Bank Equity Multiplier

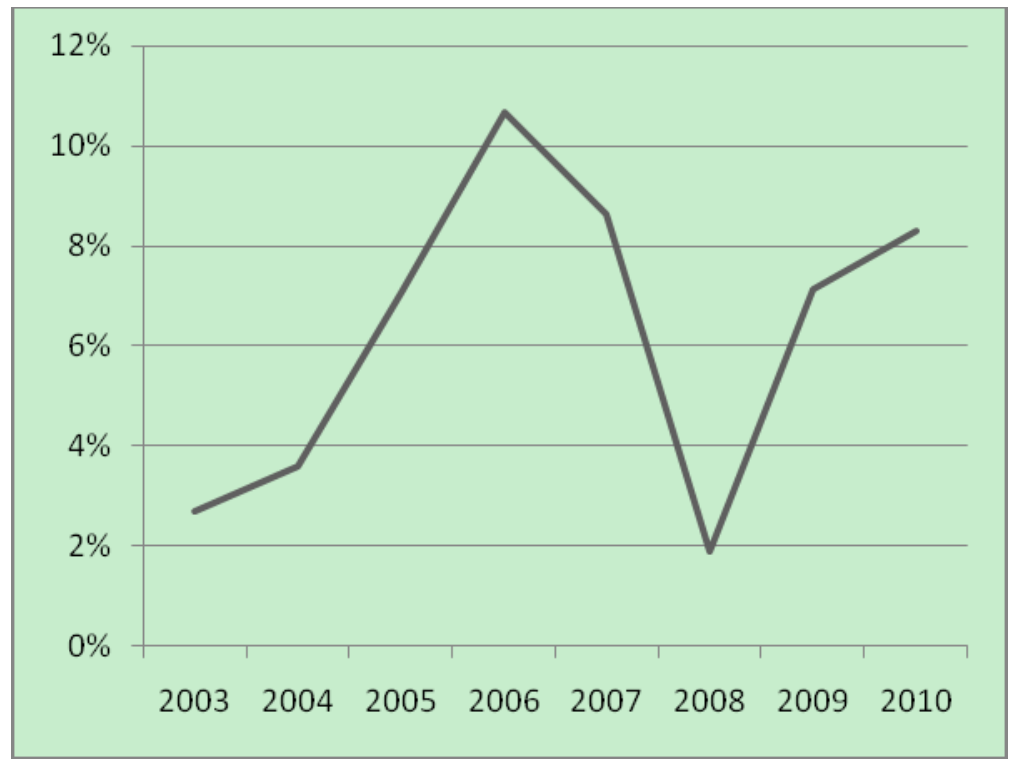

Figure 5. Monarch Bank Return on Equity 